Original article

\title{
Cumhuriyetten Günümüze Hayat Bilgisi Dersi Öğretim Programlarının Amaçlarının İncelenmesi ${ }^{1}$
}

\section{Analysing the Objectives of Life Science's Curriculums from Republic to Present}

\author{
Kerim Uçar (i) * \\ Department of Social Sciences Education, Institute of Education, Ataturk University, Erzurum, Turkey
}

\begin{abstract}
Özet
Bu çalışmanın temel amacı cumhuriyetten günümüze hayat bilgisi dersi öğretim programlarında yer alan amaçlar doğrultusunda bir değerlendirme yapmak olarak belirlenmiştir. Çalışmada nitel araştırma yaklaşımlarından faydalanılmıştır. Bu doğrultuda doküman incelemesi tekniği ile 1924’ten 2018’e kadar bütün hayat bilgisi dersi öğretim programlarının amaçları araştırılmıştır. Verilerin analizinde, betimsel analiz tekniğinden yararlanılmış ve önceden belirlenen temalar doğrultusunda veriler analiz edilmiştir.

Araştırma sonucunda hayat bilgisi dersinin ilk kez 1926 yılında programlarda yer aldığı belirlenmiştir. Bu ders toplu öğretim anlayışından hareket ederek, bazı derslerin birleşmesiyle ortaya konulmuştur. 1936 yılındaki hayat bilgisi öğretim programı, öğrenciyi ve öğrencinin çevresini aktif kılacak şekilde merkezi bir anlayışla tasarlanmıştır. 1926-1998 yılları arasında bütün hayat bilgisi dersi öğretim programlarında yaparak ve yaşayarak öğrenme modeli üstünde uygulanmıştır. Ancak bu uygulama tam olarak başarılı olmamıştır. Bu çalışma kapsamında Hayat Bilgisi Dersi Öğretim Programlarının tarihsel süreç içerisinde amaçlarındaki değişim ve gelişimler incelenmiştir. Elde edilen veriler gelecekteki çalışmalara yön teşkil edebilecektir.
\end{abstract}

Anahtar Kelimeler: Hayat bilgisi dersi, öğretim programı, tarihsel süreç.

\begin{abstract}
The main purpose of this study has been determined as to make an evaluation in line with the aims of science life science lessons curricula from the Republic to the present. Qualitative research approaches were used in the study. In this direction, the aims of all life studies lesson teaching programs from 1924 to 2018 were investigated with the document review technique. In the analysis of the data, descriptive analysis technique was used and the data were analyzed in accordance with predetermined themes.

As a result of the research, life studies lesson was determined in the programs for the first time in 1926. This lesson has been presented by combining some lessons based on collective teaching approach. The life science curriculum in 1936 was designed with a central understanding in a way to make the student and the student's environment active. Between the years of 1926-1998, it was applied on the learning model by doing and experiencing in all life studies lesson curriculums. However, this application
\end{abstract}

\footnotetext{
* Corresponding author:

Ucar K. is a teacher at the Ministry of Education, Erzurum,Turkey. His research interests include social studies and special education. He has lived, worked, and studied in Erzurum, Turkey.

Email: kerim_25@hotmail.com

${ }^{1}$ Bu çalışmanın hazırlanmasında Kerim Uçar’ın “Milli Eğitim Politikalarının Hayat Bilgisi Ders Kitaplarına Yansıması” isimli tezinden yararlanılmıştır.
} 


\section{GíRiş}

.Hayat Bilgisi eğitiminin ne zaman ve nerede başladığı kesin olarak bilinmemektedir. Yalnız "İnsanoğlu var olduğu andan itibaren hem fen, hem de sosyal bilimler eğitimi başlamıştır" denilebilir. Çünkü insan, doğal ve toplumsal bir ortamda doğar, büyür, gelişir, yaşlanır ve ölür. Bu süreç içinde ona en azından yemek, içmek, giyinmek, korunmak, savunmak, vb. etkinliklerle ilgili bilgi, beceri ve duygular kazandırılır. Eğer kazandırılmazsa, kişi yaşamını sürdüremez. Tüm bu etkinlikler doğada ve bir toplum içinde olmaktadır. İnsan, yaşamak için hem doğanın, hem de toplumun bazı özelliklerini öğrenmek zorundadır. Durum böyle ele alınınca, "fen ve sosyal bilimler insanoğlunun yasamı kadar eskidir.” savı ileri sürülebilir (Tekışık, 1997).

Sosyal bilimlerin bir parçası olan hayat bilgisi dersinin kurucusu 17. yüzyıl eğitimcilerinden J. A. Comenius'tur. Comenius, 1658 yıllarında "Orbis Sensualium Pictus" adlı eserinde, Hayat Bilgisi konularını her şeyden önce dil konularına bağlamış ve dersi ilk sınıflara uygun hale getirmiştir. $\mathrm{Bu}$ kaynak öğretimde kelimelerle eşya arasında ilişki kurma hakkında yapılmış ilk çalışmadır (Belet, 1999).

Türk eğitim tarihinde ise, İslamiyet'ten önce toplumsal ve doğal yaşamla ilgili kurallar gelenek ve göreneğin, inanç sisteminin içinde verilmiştir. İslamiyet’ten sonra ise İslam dininin esaslarına göre kişi geliştirilmeye çalışılmış, bunun yanı sıra gelenek ve görenekteki kurallar öğrenciye kazandırılmıştır (Sönmez, 1999). Osmanlı Devleti’nden itibaren ilk program çalışması Tanzimat döneminde 1847 tarihli talimatla başlatılmıştır. Bu çalışmanın 1913'te geçici ilköğretim kanunu ile genişletilmiş ve 1924'te “Tevhid-i Tedrisat Kanunu” ile Cumhuriyet ilkelerine göre uyarlanmıştır (Güven, Türkiye'de ilköğretim hayat bilgisi dersi programı değişiklikler, düzenlemeler, güncellemeler, Yüksek lisan tezi, 2010).

Türk eğitim sistemini bir bütün olarak düzenleyen bugünkü milli eğitim temel kanununa benzer ilk düzenleme 1869 yılında çıkarılan Maarif-i Umumiye Nizamnamesidir. Bu tüzükle ilköğretimin süresi dört yıl olarak belirlenmiş ve zorunlu hale getirilmiştir. 1869 dan itibaren geleneksel sıbyan mekteplerinin yanında iptidai mektep, usul-i cedide mektebi adıyla yeni okulların kurulmasıyla beraber yeni öğretim yöntemleri de ortaya çıkmaya başlamıştır (Güven, 2010).

Cumhuriyet döneminde, her düzeydeki okullarda öğrencilere, cumhuriyetçi ve demokratik bir siyasi eğitim vermek eğitimin başlıca amacıydı. Millı̂ Eğitim Bakanlığı 19 Aralık 1923 tarihli bir 
genelgesinde, "mektepler Cumhuriyet esaslarına sadık kalmayı telkine mecburdurlar" ve 8 Eylül 1924 tarihli genelgede de "çocuklarımız kalplerinde ve ruhlarında, Cumhuriyet için, fedakâr olmak mefkûresini taşımalıdırlar" denilmektedir. Cumhuriyet dönemi programlarının dayanağı 3 Mart 1924 tarihinde TBMM'de kabul edilen “Tevhid-i Tedrisat Kanunudur” (Tazebay, 2000).

Yeni kurulan Türkiye Cumhuriyeti Devleti’nin eğitim sistemi, yeni bir toplum inşa etme anlayışının ve bu toplumdaki kişilerin ihtiyaçlarını karşılayacak nitelikte olması planlanmıştır. $\mathrm{Bu}$ nedenle 1924 yılında yeni müfredat geliştirme çalışmalarına başlanmıştır. Bu süreçte hazırlanan ilköğretim müfredatları birçok kez değiştirilmiştir. Bu değişimlerden dolayı hayat bilgisi derslerinin yapısı da ciddi değişim yaşamıştır (Şahin, 2009). Yıllar bazında genel olarak bakıldığında müfredatlardaki bu değişim açık bir şekilde görülmektedir. Dönemin şartlarına bağlı olarak dar bir çerçevede başlayan müfredat geliştirmeleri sonraki yılarda önemli ölçüde genişleyerek bugünkü halini almıştır.

$\mathrm{Bu}$ bağlamda bu çalışmanın temel amacı cumhuriyetten günümüze hayat bilgisi dersi öğretim programlarında yer alan amaçlar doğrultusunda bir değerlendirme yapmaktır. $\mathrm{Bu}$ temel amaç doğrultusunda;

1. 1926-1930 İlk Mektep Müfredat Programına göre hayat bilgisi dersinin amaçları nelerdir?

2. 1936-1948 İlkokul Programlarına göre hayat bilgisi dersinin amaçları nelerdir?

3. 1962, 1965 İlkokul Program taslaklarına göre hayat bilgisi, toplum ve ülke incelemeleri derslerinin amaçları nelerdir?

4. 1968 ve 1995 İlkokul Programlarına göre hayat bilgisi dersinin amaçları nelerdir?

5. 1998 Hayat Bilgisi Dersi Öğretim Programına göre hayat bilgisi dersinin amaçları nelerdir?

6. 2005 Hayat Bilgisi Dersi Öğretim Programına göre hayat bilgisi dersinin amaçları nelerdir?

7. 2009 Hayat Bilgisi Dersi Öğretim Programına göre hayat bilgisi dersinin amaçları nelerdir?

8. 2015 Hayat Bilgisi Dersi Öğretim Programına göre hayat bilgisi dersinin amaçları nelerdir?

9. 2017 ve 2018 Hayat Bilgisi Dersi Öğretim Programlarına göre hayat bilgisi dersinin amaçları nelerdir?

\section{YÖNTEM}

Cumhuriyetten günümüze hayat bilgisi dersi öğretim programlarında yer alan amaçlar doğrultusunda bir değerlendirme yapmanın amaçlandığı çalışma nitel araştırma yaklaşımına uygun olarak tasarlanmıştır. (Denzin \& Lincoln, 2005) varlıkların ve olguların deneysel olarak incelenemeyeceği durumlarda nitel araştırmaların kullanıldığını bunun da nitel araştırmaların özgün 
tarafı olduğunu ifade etmiştir. Bu bağlamda cumhuriyetten günümüze hayat bilgisi dersi öğretim programları incelenmiş ve bu programlar araştırmanın çalışma grubunu oluşturmuştur.

Verilerin toplanmasında nitel araştırma tekniklerinden doküman incelemesinden yararlanılmıştır. Doküman incelemesi daha çok doğrudan gözlem yapılamayan durumlarda tercih edilen bir tekniktir (Yıldırım \& Şimşek, 2013). Bu doğrultuda doküman incelemesi tekniği ile 1926'dan 2018'e kadar hayat bilgisi dersi öğretim programlarının amaçları incelenmiştir.

Verilerin analizinde nitel araştırma yaklaşımlarına uygun olarak betimsel analiz tekniğinden yararlanılmıştır. Betimsel analiz tekniğine göre elde edilen veriler önceden belirlenen temalara göre özetlenir ve yorumlanır (Yıldırım \& Şimşek, 2013). Bu çalışma kapsamında hayat bilgisi öğretim programlarının her biri bir temayı oluşturmaktadır.

\section{Bulgular ve Yorumlar}

Araştırmanın temel amacına bağlı olarak oluşturulan alt amaçların her biri birer tema olarak belirlenmiş ve bulgular bu başlıklar altında sunulmuştur.

\section{6-1930 İlk Mektep Müfredat Programına Göre Hayat Bilgisi Dersinin Amaçları}

1926 Programı’nda, “ilkmektebin başlıca maksadı genç nesli muhitine faal bir halde

intibak ettirmek suretiyle iyi vatandaşlar yetiştirmektir” ilkesi temele alınmıştır. Hayat bilgisi dersine haftada 4 saat olmak üzere 1, 2 ve 3. sinıflarda yer verilmiştir. 1936 programında bu amaca; "bedence ve ruhça en iyi alışkanlıklara sahip olmak, Türk toplumuna ve cumhuriyet idaresine intibak etmek, faydalı olmak, milli, medeni ve insani fikir ve hislere sahip bir hale getirmek" gibi ilkeler eklenmiştir (Sönmez, 2005).

Bu programlarda hayat bilgisinin hedefleri dokuz madde altında toplanmıştır:

“1. İçinde yaşadığı coğrafi bölgede bulunan maden, bitki ve hayvanları çocuğa tanıtmak; etrafinda cereyan eden tabii hadiseleri inceletmek; canlı varlıkların yaşama şartlarını ve bunların birbirlerine karşı icra ettikleri tesirleri göstermek.

2. Bir taraftan suyu, havası ve toprağı ile tabii muhitin, insan üzerine yaptığı tesirleri, diğer taraftan insanın; hayvan beslemek, orman yetiştirmek, toprağı işlemek, yollar yapmak, kanallar açmak sureti ile tabiat üzerinde meydana getirdiği değişmeleri göstermek.

3. Çocuğun mensup olduğu içtimai muhitteki insanların mesai ve faaliyetlerini tetkik ettirmek. Aile, nahiye, belediye ve hükümet teşkilatını gayet müşahhas bir surette öğretmek.

4. Müşahedeye müstenit tetkiklerle çocuklara, insanın vücudu ve vücuttaki azaların vazifeleri hakkında malumat vermek. Buna müteallik hıfzıssıhha kaidelerini ameli bir surette öğretmek ve bilhassa her hususta çocukları temizliğe ve intizama alıştırmak. 
5. Mektep hayatında aile veya şehir muhitindeki insanlar arasında tahaddüs eden hakiki vakalar münakaşa edilmek veyahut hayali masallar ve hikâyeler nakletmek suretiyle çocuklara ahlâkî telkinler yapmak.

6. Mektebin bulunduğu köy veya kasaba ile civarın avarızı tetkik ettirilerek coğrafya ve yine aynı muhit dâhilinde bulunan meşhur binalarla abideler ve onlarla alakadar tarihi şahıslar hakkında malumat verilerek tarihe bir hazırlık yapmak.

7.Hayat bilgisi dersine müteallik müşahede ve tecrübeleri ve dersle alâkadar resim, el ve toprak işlerini ve koleksiyonları bizzat çocuklara yaptırmak suretiyle onları "faaliyete" sevk etmek, kendilerine işleme ve çalışma zevk ve hevesi vermek.

8.Bir taraftan çocukların tetkik ve müşahede kabiliyetlerini artırmak, diğer taraftan gördüklerini ve bildiklerini bizzat sözlü, yazılı ve iş vasıtasıyla doğru ve güzel ifadeye alıştırmak.

9. Müşterek mesai sayesinde talebe arasında yardımlaşma ve dayanışma hisleri uyandırmak ve kuvvetlendirmek (Tekışık, 1997).”

\section{6-1948 İlkokul Programlarında Hayat Bilgisi Dersinin Amaçları}

1926 programındaki bazı amaçlara 1936 programında yer verilmemekle beraber bu programa farklı amaçlar eklenmiştir. Amaçların anlatıldığı cümleler, daha soyut bir hale dönüştürülmüştür. Böylelikle 1926 programında 9 madde olan amaçlar, azaltılarak 5 maddeye düşürülmüştür. Öğretim yöntemiyle alakalı maddeler azaltılmış ve sadece "gözlem" üzerinde durulmuştur. Amaçların içerisine “estetik eğitim” ile "yurt ve ulus” sevgisi girmiştir. Hayat Bilgisi dersinin niteliği 1948 programında daha iyi vurgulanmıştır. Bu vurgulama "Hayat Bilgisi dersi, bir gözlem, yaşama, iş ve deney dersidir." şeklinde ifade edilmiştir. 1948 programında amaçlar, 1936' daki soyutluluğunu korumuş daha farklı bir şekilde ele alınmıştır (Binbaşığlu, 2003).

1948 müfredatı, bilgi öğretimini temel almıştır. 1948 programında, Millî Eğitimin amaçları; toplumsal bakımdan, kişisel bakımdan, insanlık ilişkileri bakımından ve ekonomik hayat bakımından, olmak üzere sınıflandırılmıştır. Her ders için ele alınması gereken konu ve ünite sayısı artırılarak yüklü bir içerik ortaya konulmuştur. 1948 ilkokul müfredatında da ilkokulun temel ödevlerinden birisinin “milli kültürü aşılamak” olduğu ifade edilmiştir (Şahin, 2009).

Her iki programda da hayat bilgisi dersinin amaçları değişmemiş ve iki madde altında toplanmıştır.

“1. Evde, okulda ve okulun bulunduğu köyde, kasabada ve şehirde ilk üç sınıf öğrencileri tarafından kavranması mümkün olan tabiat, tutum ve toplumsal yaşama ile ilgili gündelik hayat olaylarını çocukların gözleyip incelemelerine yardım ederken: 
a) Onlara, gündelik tabiat olaylarını doğru bir şekilde yorumlamalarını sağlayacak bilgi, tabiat güzelliklerine karşı sevgi ve tabiat ögelerinin korunması için iyi alışkanlıklar kazandırmak,

b) Öğrencilerin, evde, okulda ve çevredeki insanlarla münasebetlerinde sevgi, saygı, doğruluk, işbirliği ve sorumluluk duygularını geliştirmek suretiyle onlarda vatan ve millet bağlılığının temelini kurmak;

c) Gündelik olaylardan, her gün kullandığımız eşyadan, yakın yurdun anıtlarından, geleneklerinden ve tanınmış insanların hayatından harekete geçerek öğrencilerde tarihsel oluş fikrini uyandirmak,

d) Çocuğa çevresini ve yaşama şartlarını coğrafya bakımından gözden geçirmek.

2. Yavaş yavaş tabiat ve toplumsal yaşayışla ilgili gündelik olayların gözlenip incelenmesi sonucunda varılacak genel kavramların yardımıyla çocuklar başka başka bilim dallarına uygun bir görüş ve inceleme yoluna hazırlamak (Tekışık, 1997).”

\section{2, 1965 İlkokul Programı Taslaklarına Göre Hayat Bilgisi, Toplum ve Ülke İncelemeleri Derslerinin Amaçları}

1962 ve 1965 program taslaklarında hayat bilgisi, toplum ve ülke incelemeleri dersleri başlığı altında yer almıştır (Sönmez, 1996). 1965 tarihinde hazırlanan ilkokul program taslağında hayat bilgisi dersi, “Toplum ve Ülke İncelemeleri” adı altında sosyal bilgiler dersi ile birleştirilmiştir. Bu durum hayat bilgisi dersi açısından verimli olmamıştır. Hayat bilgisi dersi, sosyal bilgiler dersi içinde kimliğini kaybetmiştir (Sönmez, 2005).

Her iki taslak programın amaçları aşağıda sıralanmıştır:

"1.Türk çocuğu ailesine, ulusuna, yurduna, Türk Devrimlerine ve ülkülerine bağl1, çalışkan, araştırıc1, inceleyici, fedakâr ve fazilet sahibi iyi bir vatandaş, mükemmel bir insan olarak yetiştirilir.

2. Çocuklar şerefli bir geçmişi olan büyük bir milletin evlatları olduklarını duyarak; Türk ulusunun geleceğine olan güvenleri artırılır ve Türk ulusunun ülkülerini gerçekleştirmek için her fedakârllğı göze alabilecek bir karakterde yetiştirilir.

3. Olumlu karakter özellikleri kazandırmak, her yönde görev ve sorumluluk alabilecek hale getirmek, aile bütünlüğüne bağlı, yuvanın saadetini gerçekleştirmesindeki hizmet duygularını geliştirmek,

4. İnsanların birbirlerine muhtaç olduklarını kavratmak, grup faaliyetlerine katılmanın, başkalarına yardım etmenin önemini takdir ettirmek ve uygulayabilir hale getirmek,

5. Ulusal kaynakları tanımak ve bunları korumanın bir ödev olduğunu kavratıp benimsetmek, 
6. Yurdu ve dünyayı tanımak, çocuklara plan, kroki ve harita konusunda fikir vermek, onları bu araçları anlar ve uygular hale getirmek,

7. Çocuğa, uluslar ailesi içinde Türk Ulusuna düsen insanlık ödevlerini öğretmek (Ne Mutlu Türküm Diyene, Yurtta Sulh Cihanda Sulh) fikrini ve Birleşmiş Milletler ülküsünü benimsetmek.

8. Geçmişte uluslarına ve insanlara iyilikleri dokunmuş olan büyük Türk adamlarının hayatlarına ve hizmetlerine karşı öğrencilerde hayranlık uyandırmak, kötülükleri dokunan kimselerin akıbetlerinden de ibret dersi almalarını sağlamak (Sönmez, Hayat bilgisi öğretimi ve öğretmen klavuzu, 1999).”

\section{8 ve 1995 İlkokul Programlarına Göre Hayat Bilgisi Dersinin Amaçları}

1968 programı gerek hazırlanışındaki sistemli çalışmalar, gerekse geçmiş programların birikimlerini taşıması ve uluslararası deneylerden yararlanarak yapılması açısından, Tanzimat'tan günümüze kadar hazırlanmış en sistemli programdır. Bu programda toplu öğretim ilkesinden yola çıkılarak dersler; mihver dersler ( 1, 2 ve 3. sınıflar için hayat bilgisi, 4 ve 5 . sınıflar için fen bilgisi ve sosyal bilgiler ) ve ifade ve beceri dersleri (diğer dersler) olarak iki kategoriye ayrılmıştır. Mihver derslerin öğretim programları konular biçiminde değil üniteler biçiminde ayrımlaştırılmış, eğitim mihver derslerin üniteleri etrafında öbekleştirilmiştir (Çağlar, 1999). 1995 Hayat bilgisi dersi öğretim programının amaçları 1968 programından alınmıştır (Öztürk \& Dilek, 2004).

1968 yılında kabul edilen hayat bilgisi dersinin amaçlan (hedefleri) beş alt başlık altında aşağıda verilmiştir (Sönmez, 1999).

\section{“1) Yakın çevreyi tanıma ile ilgili yetenek ve becerilerin gelişmesi yönünden;}

a) Çevresinin tabii olaylarını anlar ve doğru yorumlar, bu olayların insan yaşayışına etkisini bilirler.

b) Çevreyi ve çevrenin tabii güzelliklerini severler,

a) Çevreyi tanır ve çevrenin yaşama imkânlarını inceleyerek daha iyi yaşama yollarını bulmaya çalışırlar,

d) Günlük olayları, her gün kullandığı eşyayı, yakın çevrenin eserlerini, anıtlarını inceleyerek toplumsal gelişme bilinci kazanırlar.

\section{2) Yurttaşlık görevleri ve sorumluluklart yönünden:}

a) Türk Milletine, Türkiye Cumhuriyetine, Atatürk'e ve devrimlerine karşı sevgi ve saygı duyar, onlara güvenirler,

b) Millet ve yurt işlerine karşı yakın bir ilgi duyarlar,

c) Yakın çevrede yaşamış büyük insanlar ve çevrenin gelişip ilerlemesine hizmet etmiş olanlanı tanır, onları takdir etme ve değerlendirme duygusunu kazanırlar, 
d) Demokratik davranışlara ve inanışlara sahip yurttaş olurlar,

e) Aileyi, okulu ve yurdu severler, milli duygularını kuvvetlendirirler,

f) Ailelerinin mutluluğuna en iyi şekilde nasıl yararlı olabileceklerini araştırırlar,

3) Toplumda insanların birbirleriyle olan ilişkileri yönünden:

a) Evde, okulda ve çevrede beraber yaşadıkları insanlara karşı sevgi ve saygı duyarlar,

b) Doğruluk fikri ve işlerini doğru yapma alışkanlığı kazanırlar,

c) Dayanışma, iş birliği ve sorumluluk duygularına sahip olurlar,

d) Aileyi, okulu ve çevreyi inceleyerek topluluk halinde yaşamanın önemini kavramaya ve toplumun istediği davranışları göstermeye başlarlar.

4) Ekonomik yaşama fikrini ve yeteneklerini geliştirme yönünden:

a) Ailenin geçim ve gelir durumunu dikkate alarak parasını planlı harcamaya, tutumlu olmaya ve yerli malı kullanmaya önem verirler,

b) Eşyalarını ve toplumun ortak mallarını iyi kullanır ve gerektiğinde onarırlar,

c) Üretim, tüketim ve dağıtım hakkında temel bilgiler kazanırlar,

d) Milli gelir kaynaklarını tanımaya ve gerektiği şekilde değerlendirmeye çalışırlar.

\section{5) Daha iyi yaşama yeteneklerini geliştirme yönünden:}

a) Beslenme, sağlık ve trafik kurallarını, emniyetli ve sıhhatli yasama yollarını öğrenirler,

b) Ev ve iş hayatlarını daha iyi düzenlemeye, etrafını geliştirip güzelleştirmeye içinde bulunduğu hayattan daha üstün bir yaşama seviyesine ulaşmaya çalışırlar,

c) Çalışmanın, dinlenmenin ve eğlenmenin gereğini ve zamanını kavrarlar,

d) Tarım, ticaret ve sanayi faaliyetleriyle ilgilenirler, ürünlerini tanımaya ve çevrede bulunanların üretim yollarını öğrenmeye çalışırlar"

\section{Hayat Bilgisi Dersi Öğretim Programına Göre Hayat Bilgisi Dersinin Amaçları}

Milli Eğitim Bakanlığı, 1997’de kesintisiz sekiz yıllık ilköğretim uygulamasına geçilmesiyle beraber yeni bir ilköğretim programı hazırlamıştır. Genel olarak çerçeve müfredatı özelliği taşıyan 1998 müfredatı, davranışçı yaklaşımı benimseyen bir yaklaşıma göre hazırlanmıştır. Bu yönüyle üniteler yurt genelinde ortak ihtiyaçları karşılamak üzere ana maddeler şeklinde tespit edilmiştir (Şahin, 2009).

Hayat bilgisi 1998 programında, derslerin genel hedefleri, her sınıf düzeyinde özel hedefleri ve ünitelerin hedef ve hedef davranışları yazılmıştır. Genel hedefler 26 madde halinde yazılmış, ilköğretimin ve Milli Eğitimin genel amaçlarını destekler niteliktedir. Programda 1. sınıfta 18, 2. sınıfta 
21 ve 3. sınıfta 22 hedef belirlenmiştir. Özel hedefler bilişsel, duyuşsal ve psikomotor özellikleri taşımaktadır (Güleryüz, 2008). Programın hedefleri;

“1. Türk milletinin bir bireyi olmaktan gurur duyuş

2. Türkiye Cumhuriyeti Devletinin bütünlüğünün bilincinde oluş

3.Türk milletinin kültürel değerlerini benimseyiş

4. Atatürk'e sevgi ve saygı duyuş

5. İnsanlara sevgi ve saygı duyuş

6.Kendine güven duyuş

7.Dayanışma ve işbirliği içinde olmayı alışkanlık haline getiriş

8. Yaratıcı ve eleştirici düşünmeyi alışkanlık haline getiriş

9.Aile hayatının öneminin farkında oluş

10. Okulun kendisine kazandırdıklarının öneminin farkında oluş

11. Planlı çalışmayı alışkanlık haline getiriş

12. Ülke ve dünya olaylarına duyarlı oluş

13. Sesin ve 1şı̆̆ın duyma ve görme ile ilgisini seziş

14. Atatürk ilke ve inkılaplarını temel özellikleriyle tanıyabilme

15. Çevresindeki maddeleri tanıyabilme

16. Uzayı tanıyabilme

17. Turizmin önemini kavrayabilme

18. Doğa olaylarının etkilerini kavrayabilme

19. Demokrasinin temel kurallarına uyabilme

20. Sorumluluğunu yerine getirebilme

21. Toplu yaşama kurallarına uyabilme

22. Sağlığını koruyabilme

23.Canlı ve cansız varlıkları koruyabilme

24. Bilinçli tüketici olabilme

25. Çevreyi koruyabilme

26. Teknolojik yeniliklerden yaralanabilme (Vural, 2002).” 


\section{Hayat Bilgisi Dersi Öğretim Programına Göre Hayat Bilgisi Dersinin Amaçları}

2005 Hayat Bilgisi Dersi Programında insan, biyolojik, psikolojik, sosyal ve kültürel yönleriyle bir bütün olarak ve değişimin hem öznesi hem de nesnesi olarak ele alınmıştır. Bu noktadan hareketle "birey", "toplum" ve "doğa" olmak üzere üç ana öğrenme alanı belirlenmiş, değişim de bütün bu öğrenme alanlarını kuşatan daha genel bir boyut olarak düşünülmüştür. Gerçek yaşamda bu öğrenme alanlarının içerikleri ve değişim iç içedir; bunlar sadece eğitim-öğretim amacıyla yapay olarak birbirinden ayrılabilir. Hayat bilgisi dersi için özellikle benimsenen toplu öğretim yaklaşımının da bir gereği olarak, bu öğrenme alanlarını aynı anda kuşatabilen üç tema belirlenmiştir. Programda tema adları; "Okul Heyecanım”, "Benim Essiz Yuvam” ve "Dün, Bugün, Yarın” olarak kararlaştırılmışır (MEB, 2005).

\section{Hayat Bilgisi Dersi Öğretim Programına Göre Hayat Bilgisi Dersinin Amaçları}

2009 Hayat bilgisi Öğretim Programının genel ve özel amaçları 1739 sayılı Milli Eğitim Temel Kanuna dayandırılmıştır. Bu programda değerler ayrı bir başlık altında verilmemiştir. Ancak değerlerin içeriğinde olan kişisel nitelikler yer almış ve yapılandırmacı öğretim yaklaşımına devam edilmiştir (Kale, 2015).

\section{Hayat Bilgisi Dersi Öğretim Programına Göre Hayat Bilgisi Dersinin Amaçları}

Hayat Bilgisi Dersi Öğretim Programı'nın vizyonu; temel yaşam becerilerine sahip, kendini tanıyan, sağlıklı ve güvenli bir yaşam süren, doğaya ve çevreye duyarlı, araştıran, öz güveni yüksek, çevresi ve kendisiyle barışık, millî ve manevi değerleri içselleştirmiş bireyler yetiştirmektir (MEB, 2015).

Hayat Bilgisi Dersi Öğretim Programı’nın genel amaçları, 1739 sayılı Millî Eğitim Temel Kanunu'nda ifade edilen Türk Millî Eğitimi'nin genel amaçları ve temel ilkeleri doğrultusunda öğrencilerin;

"1. Okulu ve okul içindeki ilişkileri tanımasını

2. Grupla çalışma, akranlarıyla iş birliği yapma ve sosyal katılım becerilerini geliştirmesini

3. Fiziksel ve kişisel özellikleri ile kendini tanımasını

4. Aileye ve aile içi ilişkilere dair bir anlayış geliştirerek aile ile ilgili temel değerleri içselleştirmesini

5. Kişisel bakım becerilerini geliştirmesini

6. Kaynakları verimli kullanma becerilerini geliştirmesini

7. Zamanı algılama ve etkili kullanma becerilerini geliştirmesini

8. Sağlıklı ve dengeli beslenme becerilerini ve alışkanlıklarını geliştirmesini 
9. Evde, okulda ve okulun dışında kişisel güvenliğini sağlama becerilerini geliştirmesini

10. Bilişim teknolojilerini bilinçli ve güvenli kullanım becerilerini geliştirmesini

11. Millî, manevi ve insani değerleri içselleştirmesini

12. Düşünme, sorgulama, farklı düşünceler ve çözümler üretme becerilerini geliştirmesini

13. Doğayı ve çevreyi temiz tutma ve koruma becerilerini geliştirmesini,

14. Doğa ile ilgili sorular sorabilme, gözlem yapabilme, gözlem sonuçlarını gruplama, sınıflama ve karşılaştırma yoluyla bilimsel bir anlayış geliştirmesini sağlamaktır."

Burada ifade edilen genel amaçların her birinin kazanımlarda karşılığı yer almaktadır. Öğrenme etkinliklerinin planlanmasında ve öğretim materyallerinin hazırlanmasında, genel amaçlarla kazanımlar bir bütünlük içinde değerlendirilmelidir (MEB, 2015).

\section{7 ve 2018 Hayat Bilgisi Dersi Öğretim Programlarına Göre Hayat Bilgisi Dersinin Amaçları}

Hayat Bilgisi Dersi Öğretim Programı, 1739 sayılı Milli Eğitim Temel Kanunu’nda ifade edilen Türk Millî Eğitimi’nin Genel Amaçları ile Temel İlkeleri esas alınarak hazırlanmıştır. Programın asıl amac1; temel yaşam becerilerine sahip, kendini tanıyan, sağlıklı ve güvenli bir yaşam süren, yaşadığı toplumun değerlerini özümseyen, doğaya ve çevreye duyarl1, araştıran, üreten ve ülkesini seven bireyler yetiştirmektir.

İlkokul çağındaki öğrencilere birey, toplum ve doğa ekseninde temel bilgi, beceri ve değerler kazandırmayı hedefleyen Hayat Bilgisi Dersi Öğretim Programı çerçevesinde öğrenciler;

"1. Kendini ve yaşadığı çevreyi tanır

2. Aile ve toplumun temel değerlerine sahip olur

3 Millî, manevi ve insani değerleri yaşantısal hâle getirir

4. Kişisel gelişimini sağlamak için yapması gerekenlerin farkında olur

5. Kişisel bakım becerilerini geliştirir

6. Sağlıklı ve güvenli yaşam sürme bilinci edinir

7. Sosyal katılım becerisi kazanır

8. Zamanı ve mekânı algılama becerisi edinir

9. Kaynakları verimli kullanma becerisi geliştirir

10. Öğrenmeyi öğrenme becerisi kazanır

11. Temel düzeyde bilimsel süreç becerilerini kazanır 
12. Ülkesini sever, tarihî ve kültürel değerlerini yaşatmaya istekli olur

13. Doğaya ve çevreye karşı duyarlı olur

14. Bilgi ve iletişim teknolojilerini amacına uygun olarak kullanır"

Burada ifade edilen genel amaçların her birinin kazanımlarda karşıllığı yer almaktadır. Öğrenme etkinliklerinin planlanmasında ve öğretim materyallerinin hazırlanmasında, genel amaçlarla kazanımlar bir bütünlük içinde değerlendirilmelidir (MEB 2017 \& MEB 2018).

\section{Tartışma ve Sonuç}

Hayat bilgisi dersinin gözlem, deney ve iş dersi olması itibariyle her dönemde ilkokulun en temel derslerinden biri olmuştur. Bu yönleri itibariyle de çocuğu hayata hazırlamada önemli bir paya sahiptir. Hayat bilgisi dersinin çocuğu hayata hazırlama işlevinin olması nedeniyle bu derste öğrenilen bilgi, beceri ve değerler çocukların tüm hayatlarını etkileyecek önemli işlevlere sahiptir. Ayrıca diğer dersler içinde temel oluşturması bakımından ilkokul programında önemli bir yere sahip olan hayat bilgisi dersi, çocuğa yaşamın kendisini öğretir.

Türkiye'de toplu öğretim uygulamasına geçiş, “ilkokullarda 1926 tarihli “illkokulların Müfredat Programı" ile başlamıştır. İlkokulların toplu öğretim sistemine geçmesiyle beraber öğretim yöntemlerinde de değişiklikler yaşanmaya başlamıştır. Bu durum Türkiye'de gerçekleştirilen bir eğitim devrimi olarak ifade edilebilir. Bu gelişmelerin tümü siyasal ve hukuksal devrimlerimizin eğitimdeki yansımalarıdır” (Binbaşığlu, 2009).

Hayat bilgisi dersi, Tabiat Tetkiki, Hıfzıssıhha (Sağlık Koruma Bilgisi), Coğrafya, Tarih Başlangıc1, Muhasabahat-1 Ahlakiye (Ahlak Söyleşileri), Malumat-1 Vataniye (Yurt Bilgisi) dersleri 1926 programında birleştirilerek hayat bilgisi dersi adı altında tek ders haline getirilmiş ve miğfer ders özelliği kazandırılmıştır (Binbaşığlu, 2003).

1926 ilkokul müfredatında ders isimlerinin yanı sıra amaçları, konuların işlenişi esnasında dikkat edilmesi gereken noktalar da belirtilmiştir. Bu müfredatta 1924'de Türkiye'ye davet edilen John Dewey'in raporunda, üzerinde özellikle durduğu "hayat bilgisi, toplu tedris ve iş okulu" kavramları yer bulmuştur (Şahin, 2009). Benzer şekilde birçok eğitsel kavramı, Türk eğitim müfredatına kazandırılmış ve uygulamada aktif rol üstlenen öğretmenlere uygulama yapabilmeleri için geniş bir alan ortaya çıkarmıştır (Bıkmaz, 2013). Bunlara ek olarak 1926 yılında yayımlanan ilkokul programı, "toplu öğretim” ilkesini getirmiştir (Tay \& Baş, 2015).

Bu bağlamda derslerin birbirinden kopuk olarak işlenmemeleri sağlanmış ve ilkokul 1, 2 ve 3 . sinıflarda haftada dört saat olmak üzere dersler hayat ve toplum ekseni etrafında bütünleştirilmiştir (Şahin, 2009). 1926 müfredatında her derse ait amaçlar belirlenmiş ve öğretimde uygulanacak yöntemlerde ana hatları da tespit edilmiştir. 1926 müfredatı ilke, yöntem, ders ve konular bakımından 
hem biçim hem de içerik yönünden bir reform olarak kabul edilmektedir (Gülcan, Türkeli, Parabakan, Şölen, \& Albayrak, 2003).

1930 ve 1936 programlarında, 1926 programındaki amaca; "Bedence ve ruhça en iyi alışkanlıklara sahip olmak, Türk toplumuna ve Cumhuriyet idaresine intibak etmek, faydalı olmak, milli, medeni ve insani fikir ve hislere sahip bir hale getirmek" gibi ilkeler de eklenmiştir. Dersler yeni ilkelerin eklendiği programda, tabiat ve toplumsal yaşayışla ilgili iki başlık altında toplanıp, 1. sınıfta 5, 2. sınıfta 6,3 . sınıfta 7 saat olarak programa koyularak, ders saatlerinin yaklaşık olarak $\% 50$ artırılması sağlanmıştır (Sönmez, 2005).

1930 yılında köylerde yaşayan çocuklar için şehirdeki okulların müfredatı temel alınarak, "Köy Mektepleri Müfredat Programı” hazırlanmıştır. Bu müfredat programının amaçları 1926 programıyla aynidir (Y1lmaz, 2020).

1926 ilkokul müfredatından sonra Türkiye' de değişik alanlarda devrimler yapılmıştı. Devrimlerle beraber ortaya çıkan zorunlu ihtiyaçlar karışışında müfredatlarda da değişiklik yapılmasına gereksinim duyulmuştu. Kültür Bakanlığı'nın talimatıyla 1935'de toplanan ilkokul müfredat komisyonu çalışmalara başladı. Komisyon yeni bir ilkokul müfredatı oluştururken; CHP programındaki esasları, yeni pedagojik düşünceleri ve ortaokul programlarını da göz önünde bulundurarak ihtiyaç duyulan değişiklikleri yapmayı hedefliyordu. Türk devrimlerinin süreci henüz tamamlanmadığından dolayı hazırlanan 1926 ilkokul müfredatı yeni rejimin görüşlerini tam olarak yansıtamamış ve bundan dolayı 1936 müfredatı ayrı bir önem kazanmıştı. Bu müfredatta ilkokulun hedefleri başlığını taşıyan ilk bölümünde ulusal eğitim ilkelerine yer verilmiş, daha sonra, ilkokul eğitim ve öğretim ilkeleri üzerinde durulmuştur (Şahin, 2009).

Hazırlanan 1936 programı, Cumhuriyet'in ilanından sonra yapılan birçok yeniliğin benimsetilmesi yönüyle 1926 programına benzemektedir. 1936 Hayat Bilgisi Öğretim Programı öğrenciyi ve öğrencinin çevresini aktif kılacak şekilde merkeze alan bir düşünce ile oluşturulmuştur (Türe, 2013).

1936 programında, 1926 programındaki bazı amaçlara açıkça yer vermemekle beraber farklı amaçlar da eklenmiştir. Amaç anlatan cümlelerin, daha soyut bir hale getirilmesi sağlanmıştır. Böylece 1926 programında 9 olan amaç sayısı, 5'e düşürülmüştür. Öğretim yöntemine ilişkin maddeler azaltılmış ve sadece "gözlem" üzerinde durulmuştur. Amaçlara "estetik eğitim” ile "yurt ve ulus" sevgisi eklenmiştir (Binbaşığlu, 2003).

1936 ilkokul müfredatı öğrencileri ezbercilikten kurtarmayı amaçlamıştır. Canlı mevzular etrafında, öğrencilerin gözlem ve inceleme yapmalarını sağlayarak ulusal sorunlarla da ciddi bir şekilde ilgilenmelerini sağlamayı hedef edinmiştir. Toplu öğretim, ilkokulun yöntemi olarak tespit edilmiş ancak üçüncü sınıfın sonuna doğru, öğrencilerin olayları ve cisimleri bilimsel kurallara göre inceleme 
yeteneklerinin geliştirilmesi amacıyla hayat bilgisi dersinin kademe kademe gruplara ve dallara ayrılması talep edilmiştir. 1936 ilkokul müfredatının amaçları arasında yer alan "Kuvvetli cumhuriyetçi, milliyetçi, halkçı, devletçi, laik ve devrimci yurttaşlar olarak yetiştirmek; Türk milletini ve Türk devletini çok önemseyecek ve önemsetecek düşünceleri bütün yurttaşlara aş1lamayı kendisine görev bilecek öğrenci yetiştirmek” hayat bilgisi konuları arasına da girmiştir (Akbaba, 2004).

1946 y1lında çok partili demokratik yaşama geçilmesiyle beraber, okullarda da bu demokratik yaşamın unsurlarının kazandırılması ihtiyacı ortaya çıkmıştır. Bu ihtiyacı giderebilmek için de 1948 yılında yeni bir program hazırlanarak uygulamaya başlanmıştır (Binbaşığlu, 1995).

Uygulamaya konan 1948 hayat bilgisi programı; ülkenin tamamını kapsayıcı bir uygulama alanı olarak belirlemiş, çevresel koşullar da dikkate alınarak hazırlanmış ve ünite sonlarına eğitsel sonuçlar bölümü eklenmiştir (Bektaş, 2009). 20 y1l boyunca uygulanan 1948 hayat bilgisi programında millî eğitimin amaçları, toplumsal, kişisel, insan ilişkileri ve ekonomik hayat bakımından 4 başlıkta verilmiştir (Şahin, 2009). Bu döneme ait hayat bilgisi programı da, 1936 programı gibi toplu öğretime dayalı olarak belirlenmiş ve birinci devre öğretimin temeli olarak ifade edilmiştir. Bu programın amaçlarında; toplumsal yaşam ile birlikte sevgi, saygı, doğruluk, işbirliği, sorumluluk, gelenek ve göreneklere bağl1lık, vatan-millet sevgisi ve bilimsel gözlem yapma beceri ve değerleri de yer bulmuştu (Kale, 2015).

1948 Hayat bilgisi programının; beklenenin tersine öğrencilerin bilişsel düzeylerinin üstünde içeriğe sahip olması, duyuşsal ve psikomotor becerilerin kazandırılmasına uygun olmaması, esnek olmaması ve ekonomik şartların yeterli olup olmamasına bakılmaksızın uygulanmak zorunda kalınması gibi nedenlerden dolayı yeni bir program ihtiyacı ortaya çıkmıştır (Bektaş, 2009).

1962 program taslağında hayat bilgisi, toplum ve ülke incelemeleri dersleri başlığ verilmiştir (Sönmez, 1996). 1965 tarihli “illkokul Program Taslağı”, 1968 programının hazırlanması sırasında deneme niteliğinde çıkarılmış ve bazı okullarda uygulaması yapılmıştır. Bu program taslağında hayat bilgisi dersi sosyal bilgiler dersi ile birlikte toplum ve ülke incelemeleri adı altında yer almış ancak bu uygulamadan bir verim alınamamıştır (Binbaşığlu, 2003).

1948 programının değerlendirilmesiyle elde edilen birçok rapor göz önünde bulundurularak 1962 ve 1965 yıllarında hazırlanan program taslakları yapılan uygulamalar neticesinde 1968 yılında son hâli verilerek bütün ilkokullarda uygulanmaya başlanmıştır. 1968 programı; normal, çift öğretim yapan ve birleştirilmiş sınıflarda faaliyette bulunan okullarda uygulanırken ortak bir anlayışa varmak, kullanılacak yöntem ve tekniklerde görüş birliğini sağlamak, uygulamaları kolaylaştırmak ve böylece yüksek verim elde etmek amacıyla hazırlanmıştır (Yolcu , 2014).

1968 programı gerek hazırlanışındaki sistemli çalışmalar, gerekse geçmiş programların birikimlerini taşıması ve uluslararası deneylerden yararlanarak yapılması bakımından, Tanzimat'tan 
günümüze kadar en sistemli program olarak hazırlanmıştır. Bu programda toplu anlayışından yola çıkılarak dersler; mihver dersler (1, 2. ve 3. sınıflar için hayat bilgisi, 4 ve 5. sınıflar için fen bilgisi ve sosyal bilgiler) ve ifade ve beceri dersleri (diğer dersler) şeklinde kategorilere ayrılmıştır. Mihver derslerin öğretim programları, konular biçiminde değil üniteler biçiminde parçalanmış, eğitim mihver derslerin üniteleri etrafında kümelendirilmiştir (Çağlar, 1999).

1948 programının aksine 1968 programında duyuşsal ve devinimsel kazanımların da ön plana çıkarılmıştır. Hedefler boyutuyla incelendiğinde 1968 hayat bilgisi programında hedeflerin tamamıyla öğrenciye dönük hale getirildiğini görmek mümkündür (Sönmez, 1999).

1995 yılındaki öğretim programı, hayat bilgisi dersine sadece Atatürkçülük konularını eklemiş ve 1968 programındaki hedefleri almıştır. 1995 programı, hedefler yakın çevreyi tanıma ile ilgili; yurttaşlık görevleri ve sorumlulukları, toplumda insanların birbirleriyle olan ilişkileri, ekonomik yaşama fikrini ve yeteneklerini geliştirme ve daha iyi yaşama yeteneklerini geliştirme yönünden olmak üzere beş başlık altında toplamıştır (Sönmez, 1999).

1998 yılında geliştirilen yeni hayat bilgisi programının bir önceki programdan en önemli farkı çağdaş program geliştirme ilkelerine uygun olarak hazırlanmasıdır. Bu programda derslere ilişkin genel hedeflerle birlikte her derse ilişkin özel hedeflere ve davranışsal hedeflere de yer almıştır (Yıldız, 2009).

1998 yılında uygulanmaya başlanan hayat bilgisi programının başlangıcında "Programın Uygulanması ile İlgili Esaslar” bölümü yer almıştır. Ayrıca öğrenme öğretme etkinlikleri, yöntemler, kaynaklar, videokasetler, ölçme, değerlendirme bölümleri ve bunlara ek olaraktan örnek sorulara yer verilmiştir. Her sınıf sonunda belirtke tablolarına yer almıştır. Önceki programlarda ölçme değerlendirmeye yer verilmezken bu programda ölçme değerlendirmeye yer verilmiştir (Yılmaz, 2020).

Hedefler boyutuyla 1926'dan başlayarak 1998 programı dâhil olmak üzere hazırlanan tüm programlarda, öğrenmede, yaparak yaşayarak öğrenme modeli üstünde durulmasına karşın tam olarak bunun başarılamadığını söyleyebiliriz. 2004 yılında hazırlanan ve bir yıl pilot illerde denenen hayat bilgisi programı 2005 y1lında uygulamaya koyulmuştur (Tay \& Baş, 2015).

2005 hayat bilgisi dersi öğretim programı dünyada gerçekleştirilen program geliştirme çalışmalarından etkilenen, yapılandırmacı anlayışın hâkim olduğu çocuğu merkeze alan, yaparak yaşayarak öğrenmeyi savunan bir anlayışla hazırlanmıştır. Programın içeriği ve yapısı incelendiğinde, kendinden önceki programlara göre oldukça ayrıntılı hazırlandığı, programın hazırlanma gerekçelerinin ve aşamalarının detaylı olarak açıklandığı, hedef / davranışların kazanım sözcüğü ile ifade edildiği, öğretme - öğrenme ve değerlendirme süreçlerinde öğretmenlere yol gösterecek ayrıntılı açıklamalara yer verildiği görülmektedir. Programın bu haliyle, Cumhuriyet dönemindeki en kapsamlı ilkokul programı olduğunu söyleyebiliriz (Aktepe \& Gündüz, 2020). 
2005 ilköğretim müfredat1, Türkiye Cumhuriyeti projesinin gelişerek devamlılı̆̆1 ilkesini, dünyada yaşanan tüm gelişmeleri, $\mathrm{AB}$ normlarını ve eğitim anlayışını, Türkiye'nin mevcut eğitim özelliklerinin belirlenmesini, başarı ve başarısızlıkların değerlendirilmesini ve ortaya çıkan sonuçları, temel referans noktaları olarak kabul edeceğini beyan etmiştir. İlkokul ve ortaokul mantığına göre düzenlenmiş olan parçalı müfredat anlayışı yerine, müfredatlar sekiz yıllık kesintisiz eğitime uygun hâle getirilerek düzenlenmiştir (Şahin, 2009).

2005 hayat bilgisi öğretim programı 22 Nisan 2009'da Danıştay 8. dairesi tarafından iptal edilmiştir. Yapılan çok yönlü değerlendirmeler ve bilimsel çalışmaların sonuçları göz önünde bulundurularak küçük değişikliklerle oluşturulan 2009 hayat bilgisi programı 2009-2010 eğitim-öğretim yılından itibaren uygulamaya başlanmıştır. 2005 programında yapılan küçük değişikliklerle 2009 yılında oluşturulan Hayat Bilgisi programının ortaya çıkarmıştır. 2010 yılında ders saatinde değişikliğe gidilerek 5 saat olan ders 4 saate düşürülmüştür (Yar Sevmiş, 2020).

2015 Hayat Bilgisi programı 2015-2016 eğitim-öğretim yılı ile birlikte 1. Sınıflardan başlayarak tüm ilkokullarda sistemli olacak şekilde uygulanmaya başlamıştır. 2015 hayat bilgisi öğretim programı yapılandırmacı yaklaşımı temel olarak almıştır. Ancak programda eski programlara göre önemli değişiklikler ortaya konulmuştur. Bu programda göze çarpan önemli değişikliklerden biri ünite temelli yaklaşımın benimsenmesidir. Her sınıf için ayrı ayrı belirlenen üniteler ile kazanımlar eşleştirilmiştir. Yine beceri ve değerler eğitimi detaylı şekilde açıklanmıştır. Ancak 2005 yılı programında yer alan örnek etkinlikler, örnek ölçme ve değerlendirme örnekleri bu programda yer almamıştır (Yar Sevmiş, 2020).

2015 hayat bilgisi dersi öğretim programı sadece 2016 - 2017 eğitim-öğretim döneminde birinci sınıflarda uygulanmış ikinci ve üçüncü sınıflarda uygulanmamıştır. 2017 hayat bilgisi dersi öğretim programının oluşturulması ile 2015 hayat bilgisi dersi öğretim programı yürürlükten kaldırılmıştır (Akyürek Tay \& Baş, 2017).

2017 y1lında taslak öğretim programı oluşturularak 1 ay süreyle öğretmen ve akademisyenlerin görüşüne sunulmuş ve bu doğrultuda son şeklini almıştır. Yine ünite temelli yaklaşımın benimsendiği bu programda her sınıf düzeyi için altı ünite belirlenmiş ve her ünite altında kazanım açıklamalarına yer verilmiştir. Ayrıca her sınıf için öğrencilerden beklenen unsurlar açıklanmıştır. Yine öğretmenlerin dikkat etmesi gereken unsurlara yer verilmiştir (Yar Sevmiş, 2020).

2018 Hayat bilgisi öğretim planı, 1739 sayı1ı Milli Eğitim Temel Kanunu’nda yer alan Türk Milli Eğitimi’nin Genel Amaçları ile Temel İlkeleri göz önünde bulundurularak hazırlanmıştır. Programın esas amacı; temel yaşam becerilerini kazanmış, kendini bilen, sağlıklı ve güvenli bir hayat süren, toplum değerlerini özümsemiş, doğaya ve çevreye duyarlı, araştırmayı ve üretmeyi seven ve vatanını seven bireyler yetiştirmektir (MEB, 2018). 
2017 y1lı ile hemen hemen aynı içeriğe sahip 2018 yılı öğretim programında yetkinlik ve değerlere vurgu yapılarak, üniteler, kazanımlar açıklanmıştır. 2017 programına yön veren eğitim felsefesi ile 2018 programının felsefesi, kazanımları, öğrenme-öğretme süreçleri ve ölçme değerlendirme boyutlarında herhangi bir değişiklik yapılmayarak aynen korunmuştur (Yar Sevmiş, 2020).

21. yüzyılda farklı beceri ve yetkinliklerle donanmış bireyler yetiştirmek yaşamın gereklerinden biridir. Ayrıca ahlaki çöküntünün yaşandığı bu çağda karakter ve değerler eğitimine olan ihtiyaç her geçen gün artmaktadır. Çocukları hayatla tanıştıran, hayata hazırlayan ve çağımızın insanı özellikleri kazandıran hayat bilgisi dersi, cumhuriyetten günümüze kadar tüm programların yapı taşı olmuştur. Dersin en önemli özelliklerinden birisi de disiplinler arası yapısıyla tüm derslere temel olma ve tüm dersleri kapsamasıdır. Bu nedenle program geliştirme çalışmalarında çağın ihtiyaçları ve gelişimleri doğrultusunda sürekli yenilenmiş ve güncellenmiştir (Yar Sevmiş, 2020).

\section{Sonuç}

Bu sonuçlar doğrultusunda aşağıdaki öneriler sunulmuştur. Bu çalışma kapsamında Hayat Bilgisi Dersi Öğretim Programlarının tarihsel süreç içerisinde amaçlarındaki değişim ve gelişimler incelenmiştir. Benzer bir çalışma ile Programların farklı boyutları incelenebilir. Tarihsel süreç içerisinde Hayat Bilgisi Dersi Öğretim Programları ile siyasal ve sosyal gelişmeler ilişkilendirilerek programa yansıması incelenebilir.

\section{KAYNAKÇA}

Akbaba, T. (2004). Cumhuriyet döneminde program geliştirme çalışmaları. Bilim ve Aklın Aydınlı̆̆ında Eğitim Dergisi , 4(54-55).

Aktepe, V., \& Gündüz, M. (2020). Kuramdan uygulamaya hayat bilgisi ögretimi. Ankara: Pegem Akademi.

Akyürek Tay, B., \& Baş, M. (2017). Cumhuriyetten günümüze hayat bilgisi öğretim programlarına karşılaştırmalı bakış. In B. Tay, Ş. Uçuş Güldalı, \& M. Baş, Etkinlik örnekleriyle hayat bilgisi ögretimi. Ankara: Pegem Akademi.

Bektaş, M. (2009). Hayat bilgisi dersinin dünü bugünü. In S. Ögülmüş, İlköğretim hayat bilgisi ögretimi ve ögretmen el kitabı. Ankara: Pegem A yaynıcılık.

Belet, D. (1999). İköğretim kurumlarında uygulanan hayat bilgisi programının değerlendirilmesi, Yüksek lisans tezi. Eskişehir: Anadolu Üniversitesi Sosyal Bilimler Enstitüsü.

Bıkmaz, F. (2013). 1924 İlkmektepler müfredat programı Doç. Dr. In D. Gözütok, \& F. B1kmaz, Cumhuriyet in ilanından 2013 `e ögretim programlarının analizi hayat bilgisi örneği. Ankara: Yarg1 yayınevi.

Binbaşığlu, C. (1995). Türkiye'de Eğitim Bilimleri Tarihi. İstanbul: Milli Eğitim Bakanlığı Yayınları.

Binbaşığlu, C. (2003). Hayat bilgisi öğretimi. Ankara: Nobel Yayın Dağıtım.

Binbaşığlu, C. (2009). Başlangıçtan günümüze Türk eğitim tarihi. Ankara: Anı Yayınc1lık. 
Çağlar, A. (1999). 75. Yılında Cumhuriyet'in ilkoğretim Birikimi. In F. Gök, 75 yılda eğitim. İstanbul, Tarih Vakfi Yayınları.

Denzin, N., \& Lincoln, Y. (2005). The sage handbook of qualitative research. (Third Edition). California: Sage Publications.

Gülcan, M., Türkeli, Y., Parabakan, F., Şölen, A., \& Albayrak, F. (2003). Türkiye'de ilköğretim dünü, bugünü, yarını. İstanbul: Milli Eğitim Basımevi.

Güleryüz, H. (2008). Hayat bilgisi öğretimi ve programı. Ankara: Pegem Akademi.

Güven, M. (2010). Türkiye'de ilköğretim hayat bilgisi dersi programı değişiklikler, düzenlemeler, güncellemeler. Konya: Selçuk Üniversitesi Eğitim Bilimleri Enstitüsü İlköğretim Ana Bilim Dalı Sosyal Bilgiler Eğitimi Bilim Dalı.

Güven, M. (2010). Türkiye'de ilköğretim hayat bilgisi dersi programı değişiklikler, düzenlemeler, güncellemeler, Yüksek lisan tezi. Konya: Selçuk Üniversitesi Eğitim Bilimleri Enstitüsü.

Kale, M. (2015). Hayat bilgisi ders kitaplarında yer alan değerlerin içerik analizi (1948-2012), Yüksek lisans tezi. Ankara: Gazi Üniversitesi Eğitim Bilimleri Enstitüsü.

MEB. (2005). İlköğretim hayat bilgisi dersi öğretim programı ve klavuzu (1, 2 ve 3. sinıflar). Ankara: Milli Eğitim Bakanlığı.

MEB. (2015). Illkokul hayat bilgisi dersi programı (1, 2 ve 3. sinıflar) öğretim programı. Ankara: Milli Eğitim Bakanlı̆̆ı.

MEB 2017, \& MEB 2018. (2017-2018). Hayat bilgisi dersi öğretim programı (İlkokul1, 2 ve 3, sinıflar). Ankara: Miili Eğitim Bakanlığı.

MEB. (2018). Hayat bilgisi dersi ögretim programı (1, 2 ve 3. sinıflar). Ankara: Milli Eğitim Bakanlığı.

MEB. (2018). Hayat bilgisi dersi ögrretim programı (İlkokul 1, 2 ve 3. sinıflar). Ankara: Milli Eğitim Bakanlığı.

Öztürk, C., \& Dilek, D. (2004). Hayat bilgisi ve sosyal bilgiler öğretim programları. In C. Öztürk, \& D. Dilek, Hayat Bilgisi ve Sosyal Bilgiler Öğretimi. Ankara: Pegem A yayıncılık.

Sönmez, V. (1996). Hayat bilgisi öğretimi ve öğretmen klavuzu. Ankara: Pegem yayınc1lık.

Sönmez, V. (1999). Hayat bilgisi öğretimi ve öğretmen klavuzu. İstanbul: Milli Eğitim Bakanlığı Yayınları.

Sönmez, V. (2005). Hayat ve sosyal bilgiler öğretimi ve öğretmen kilavuzu (5 ed.). Ankara: Anı yayıncılık.

Şahin, M. (2009, 8 2). Cumhuriyetin kuruluşundan günümüze Türkiye'de hayat bilgisi dersi programlarının gelişimi. Uluslararası Sosyal Araştırmalar Dergisi.

Tay, B., \& Baş, M. (2015). 2009 Ve 2015 Yılı hayat bilgisi dersi öğretim programlarının karşılaştırılması. Bayburt Üniversitesi Eğitim Fakültesi Dergisi, X(II).

Tazebay, A. (2000). İlköğretim programları ve gelişmeler. Ankara: Nobel yayınları.

Tekışık, H. (1997). Birleştirilmişs sınıflar için hayat biligisi 2. sınıf. Ankara: Tekışık yayıncılık.

Türe, E. (2013). 1936 İlkokul Programı (Hayat Bilgisi Dersi). In F. Gözütok, \& F. Bıkmaz, Cumhuriyet in ilanından 2013 `e ögretim programlarının analizi hayat bilgisi örneği. Ankara: Yargı yayınevi.

Vural, M. (2002). İlkögrretim okulu programı. Erzurum: Yakutiye yayıncılık ve bilgi işlem merkezi. 
Yar Sevmiş, B. (2020). Hayat bilgisi dersi öğretim programı. In M. Gültekin, Cumhuriyet dönemi ilkokul programları. Ankara: Pegem Akademi.

Yıldırım, A., \& Şimşek, H. (2013). Sosyal Bilimlerde Nitel Araştırma Yöntemleri (9 ed.). Ankara: Seçkin Yayınevi.

Yıldız, S. (2009). 2005 Hayat bilgisi dersi öğretim programının birlestirilmiş sinıflarda uygulanabilirliğinin ögretmen görüslerine göre değerlendirilmesi (Nitel bir arastırma), Yüksek lisans tezi. Afyonkarahisar: Afyon Kocatepe Üniversitesi Sosyal Bilimler Enstitüsü İlköğretim Anabilim Dalı.

Yılmaz, F. (2020). 2018 Hayat bilgisi öğretim programının öğretmen görüşlerine göre değerlendirilmesi: İstanbul ili örneği, Yüksek lisans tezi. Düzce: Düzce Üniversitesi Sosyal Bilimler Enstitüsü Temel Eğitim Anabilim Dalı.

Yolcu , O. (2014). Cumhuriyetten (1923) günümüze (2013) ilköğretim birinci kademe hayat bilgisi ve fen ve teknoloji ögretim programlarının "çevre eğitimi" açısından incelenmesi. Aydın: Adnan Menderes Üniversitesi Sosyal Bilimler Enstitüsü Eğitim Bilimleri Anabilim Dalı. 